\title{
Analysis of Allelochemicals in the Leaves of Four Alpine Rhododendrons by Gas Chromatography-Mass Spectrometry
}

\author{
Yannan Pan, Wenxuan Quan, Chaochan Li,* Jiangtao Hao, and Yongdao Gao \\ Field investigations conducted in the wild alpine rhododendron forest in \\ the Baili Rhododendron Nature Reserve found that the natural \\ regeneration of the forest was hindered. This paper used GC-MS to \\ identify and analyze the most abundant chemical compounds in the leaves \\ of four of rhododendron species (Rhododendron simsii, Rhododendron \\ decorum, Rhododendron liliiflorum, and Rhododendron pulchrum). The \\ results showed that the chemical substances in the four rhododendron leaf \\ samples were mainly aldehydes, alcohols, and esters. Among them, the \\ ester content in the leaves of $R$. simsii is the most abundant, the alcohol \\ content in the $R$. decorum is the most abundant, and the aldehyde content \\ in the $R$. liliiflorum is the most abundant. These results are conducive to \\ the protection of the rhododendron ecosystem and laid a scientific \\ foundation for studying the difficulties of natural regeneration of \\ rhododendron communities.
}

Keywords: Rhododendron; Leaves; GC-MS; Allelochemical

Contact information: Key Laboratory of Mountainous Environmental Protection, Guizhou Normal University, Guiyang 550001, China; *Corresponding author's email: chaochanli@gznu.edu.cn

\section{INTRODUCTION}

The Baili Rhododendron Nature Reserve is the largest low to mid altitude native rhododendron forest at its latitude on earth, and it enjoys the reputation of being "the earth ribbon" and "the world garden" (Chen et al. 2008). Thousands of tourists visit the reserve annually, creating a huge economic value that has driven local economic development. However, according to field surveys, the flowering periods of the Baili rhododendron forests are gradually shortening, and seedlings have become increasingly rare. This has become an area of interest, with many scholars investigating the causes for the shift in flowering period and the difficulty in natural regeneration of rhododendron forest communities.

Forest community regeneration refers to the process by which tree species expand, from seed germination and seedling formation, to finally settling in a favorable environment. Allelopathy is one phenomenon affecting the formation, development, and succession of forest communities. Allelopathy occurs when certain metabolites that impact the germination, growth, and development of certain plants are released by other plants; allelopathic interactions can occur both interspecifically or intraspecifically (Christina et al. 2015). Allelopathy can act as a biological stressor that makes the regeneration of forest communities difficult, and it has become the focus of much of the research on natural regeneration disorders of forest communities (Tomar et al. 2015). Various chemical substances found in abundance in wild rhododendron communities (it is currently unclear which one is specific) can inhibit seed germination, thereby affecting the natural 
regeneration of the community (Nilsen et al. 1999; Chou et al. 2010). For example, dihydridiconiferyl alcohol inhibits the germination of lettuce (Carillo et al. 2010). Polyacetylenes cis-dehydromatricaria ester, lachnophyllum ester, and matricaria ester have certain allelopathic effects on rice growth and seed germination; a high concentration of vanillin causes eggplant autotoxicity and was found to increase the risk of disease (Shaoli et al. 2011). The germination of seeds and the growth of seedlings are highly vulnerable stages, but absolutely critical for forest regeneration. Studies have shown that the forest community of the Baili Rhododendron Nature Reserve is rich in allelochemicals (Fu et al. 2019; Li et al. 2019). Therefore, it is necessary to understand the effect of these allelochemicals on forest regeneration, and in-depth empirical investigations into the metabolites released in the Baili rhododendron community are required. This study used GC-MS to determine the allelochemical composition in the leaves of four rhododendron species.

\section{EXPERIMENTAL}

\section{Overview of the Research Site}

The Baili Rhododendron Nature Reserve is located at the junction of Qianxi County and Dafang County in Guizhou Province in southwest China (Fig. 1). The coordinates are $105^{\circ} 45^{\prime} \sim 106^{\circ} 04^{\prime} \mathrm{E}$ and $27^{\circ} 08^{\prime} \mathrm{N} \sim 27^{\circ} 20^{\prime} \mathrm{N}$, and the altitude is 1500 to $1800 \mathrm{~m}$. The average relative humidity of the area is $84 \%$. It has a northern subtropical humid monsoon climate. The lowest and highest average monthly temperatures are $2{ }^{\circ} \mathrm{C}$ (January) and $21{ }^{\circ} \mathrm{C}$ (September). The annual precipitation ranges between 1000 and $1100 \mathrm{~mm}$.

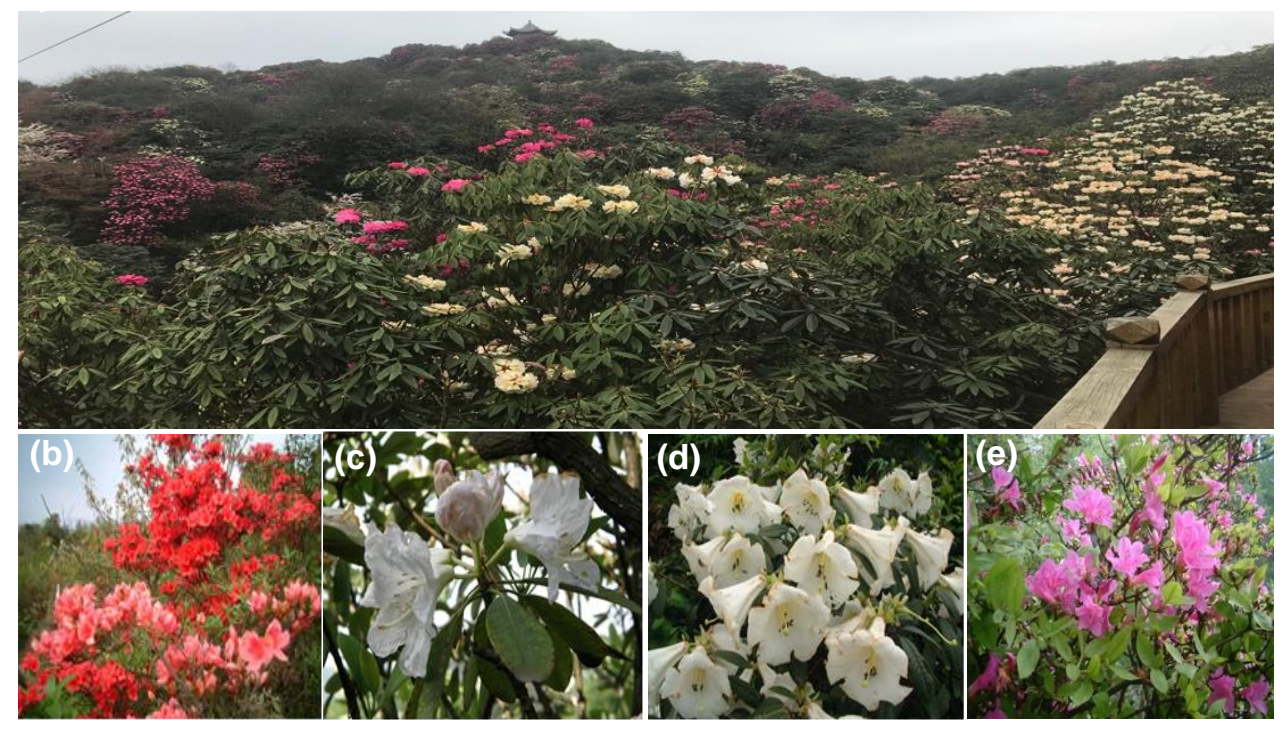

Fig. 1. (a) Location and overview of the Baili Rhododendron Nature Reserve in China, (b) Rhododendron simsii Planch, (c) Rhododendron decorum Franch, (d) Rhododendron liliiflorum Levl, and (e) Rhododendron pulchrum Sweet

\section{Sample Processing}

From April 2 to 3, 2015, fresh leaves of R. simsii, R. decorum, R. liliiflorum, and R. pulchrum were collected from the Baili Rhododendron Nature Reserve. The leaf samples were processed using two methods: (1) leaves were placed in a large clean Erlenmeyer flask and soaked in acetone for $90 \mathrm{~min}$. The acetone solution was saved for 
analysis, and the leaves were wrapped in tin foil for testing. (2) Leaves were directly wrapped in tin foil and brought back to the laboratory. Three samples of each leaf were weighed, and exactly $5 \mathrm{~g}$ of each was soaked in acetone for $24 \mathrm{~h}$, after which the extract was filtered. GC-MS analysis was then performed on $1.0 \mu \mathrm{L}$ of the three different treatment solutions.

\section{Test Standards and Methods}

Specimens were prepared using the headspace solid phase microextraction method (Chaintreau et al. 2018). The sample was gently crushed into a $30 \mathrm{~mL}$ sample bottle. The solid phase microextraction program was set up. The solid phase microextraction needle was first aged at $250{ }^{\circ} \mathrm{C}$ for $30 \mathrm{~min}$ at the $\mathrm{GC}$ inlet. Then the sample was controlled by the program for automatic solid-phase micro-extraction adsorption, and analyzed by GC/MS.

Instruments, reagents, and chemical analysis: the compositions of volatile chemicals in leaf specimens were analyzed using a gas chromatography-mass spectrometry (Agilent7890A/5975C GC/MSD; Agilent Technologies, Santa Clara, CA, USA) system operating in EI mode, with an HP-5 MS capillary column $(30 \mathrm{~m} \times 0.25 \mathrm{~mm}$ ID, film thickness $0.25 \mathrm{~mm}$ ) coupled directly to the MS. The carrier gas was helium, with a flow rate of $1.0 \mathrm{~mL} / \mathrm{min}$. The oven temperature proceeded through a program of $50{ }^{\circ} \mathrm{C}$ for 1 min, then 50 to $260^{\circ} \mathrm{C}$ at $10^{\circ} \mathrm{C} / \mathrm{min}$, and subsequently held steady for $15 \mathrm{~min}$. The injector port was held at $250{ }^{\circ} \mathrm{C}$, the detector at $280{ }^{\circ} \mathrm{C}$, and the split ratio was 1:50. Mass spectrometry recordings were taken at $70 \mathrm{eV}$; scan time $1.5 \mathrm{~s}$; mass range 20 to $625 \mathrm{amu}$. Chem Station software was used to handle mass spectra and chromatograms. Compounds were identified based on their mass spectra (compared with RTLPEST3.L and NIST05.L).

\section{RESULTS AND DISCUSSION}

Allelopathy can be an important factor in the natural regeneration of forests (Jensen et al. 2011). It is broadly defined as any chemically mediated interaction between plants, but is generally referred to as an inhibitory mechanism (Rice 1984). In recent years, ecological research on allelopathic interactions within plant communities has increased significantly, and significant progress has been made (Touceda-González et al. 2015). Allelochemicals enter the environment through leaching, volatilization, plant decomposition, and root exudates (Rice 1984; Weir et al. 2004), and they affect the growth and development of plants that are close in proximity (Wu et al. 2011).

The Baili Rhododendron Nature Reserve is the largest wild rhododendron forest in China. It has ecological, scientific, and cultural value, and it is of the utmost importance to protect the species in this community. Comprehensive field surveys of the rhododendron community in the Baili Reserve have found very few new seedlings under the canopy of the rhododendron forest. The reasons behind this are unknown, making research into possible causes a top priority. Studies have shown that allelochemicals in the Baili rhododendron forest community are found primarily in the litter layer, which may inhibit forest regeneration (Li et al. 2019). Therefore, this study used GC-MS to identify and analyze the chemical compounds in the leaves of four rhododendron species and their relative composition, and it was found that they contained low molecular weight alcohols, aldehydes, and ester compounds. All these compounds have the potential to affect the germination of rhododendron seeds. Allelopathy within the rhododendron forest community is not surprising; it has been observed that soils where Ericaceae plants were

Pan et al. (2021). "Rhododendron leaf allelochemicals," BioResources 16(2), 3096-3102. 3098 
grown can limit the growth of crops (Rice 1984). This study identified 20 chemical substances in the leaves of $R$. simsii, $R$. decorum, $R$. liliiflorum, and $R$. pulchrum using GCMS, even after excluding unidentified low-content compounds. The identification of compounds in the leaves of different rhododendron varieties demonstrated the differences in their chemical compositions.

Table 1. Allelochemicals in Leaves of four Rhododendron spp.

\begin{tabular}{|c|c|c|c|c|c|c|c|}
\hline & Compound & Formula & \begin{tabular}{|c|} 
Retention \\
Time \\
(min)
\end{tabular} & R. simsii (\%) & R. decorum (\%) & R. Iiliiflorum (\%) & R. pulchrum (\%) \\
\hline 1 & Z-3-Hexenal & $\mathrm{C}_{6} \mathrm{H}_{10} \mathrm{O}$ & 5.15 & 16.52 & - & 28.55 & 23.51 \\
\hline 2 & (Z)-2-Hexenal & $\mathrm{C}_{6} \mathrm{H}_{10} \mathrm{O}$ & 6.38 & 15.72 & 16.11 & 34.92 & 18.29 \\
\hline 3 & 3-Hexen-1-ol & $\mathrm{C}_{6} \mathrm{H}_{12} \mathrm{O}$ & 6.51 & 41.07 & - & 17.04 & 29.65 \\
\hline 4 & E-3-Hexenol & $\mathrm{C}_{6} \mathrm{H}_{12} \mathrm{O}$ & 6.58 & - & 47.13 & - & 17.07 \\
\hline 5 & 2-Octen-1-ol & $\mathrm{C}_{8} \mathrm{H}_{16} \mathrm{O}$ & 6.67 & 一 & 11.95 & - & 一 \\
\hline 6 & B-Pinene & $\mathrm{C}_{10} \mathrm{H}_{16}$ & 7.08 & - & - & 0.48 & - \\
\hline 7 & Sorbaldehyde & $\mathrm{C}_{6} \mathrm{H}_{8} \mathrm{O}$ & 7.78 & 2.52 & 0.55 & 2.66 & 0.42 \\
\hline 8 & Limonene & $\mathrm{C}_{10} \mathrm{H}_{16}$ & 8.08 & 一 & 0.89 & 1.81 & - \\
\hline 9 & $\beta$-Cymene & $\mathrm{C}_{10} \mathrm{H}_{14}$ & 8.41 & - & 2.87 & - & - \\
\hline 10 & $\begin{array}{l}\text { 2-Hexenyl } \\
\text { acetate }\end{array}$ & $\mathrm{C}_{8} \mathrm{H}_{14} \mathrm{O}_{2}$ & 8.53 & 15.27 & 11.79 & - & - \\
\hline 11 & $\begin{array}{l}\text { 2-Hexen-4- } \\
\text { olide }\end{array}$ & $\mathrm{C}_{6} \mathrm{H}_{8} \mathrm{O}_{2}$ & 9.62 & 1.14 & 0.60 & 2.41 & 2.04 \\
\hline 12 & Linalol & $\mathrm{C}_{10} \mathrm{H} 1{ }_{8} \mathrm{O}$ & 10.75 & 3.69 & - & 一 & 一 \\
\hline 13 & $\begin{array}{l}\text { Benzoic Acid, } \\
\text { Methyl Ester }\end{array}$ & $\mathrm{C}_{8} \mathrm{H}_{8} \mathrm{O}_{2}$ & 10.93 & - & 2.82 & - & 1.37 \\
\hline 14 & \begin{tabular}{|c|} 
Pyrocatechol \\
Dimethyl Ether
\end{tabular} & $\mathrm{C}_{8} \mathrm{H}_{10} \mathrm{O}_{2}$ & 12.23 & - & 4.48 & - & - \\
\hline 15 & Decanal & $\mathrm{C}_{10} \mathrm{H}_{20} \mathrm{O}$ & 12.70 & 一 & 一 & 0.58 & 一 \\
\hline 16 & $\alpha$-Terpineol & $\mathrm{C}_{10} \mathrm{H}_{18} \mathrm{O}$ & 12.83 & 1.77 & 一 & 一 & - \\
\hline 17 & $\begin{array}{c}\text { Methyl 2- } \\
\text { Oxohexanoate }\end{array}$ & $\mathrm{C}_{7} \mathrm{H}_{10} \mathrm{O}_{4}$ & 12.93 & - & - & 4.21 & 5.29 \\
\hline 18 & $\begin{array}{c}2,2,5- \\
\text { Trimethyl-3- } \\
\text { Hexanone }\end{array}$ & $\mathrm{C}_{8} \mathrm{H}_{16} \mathrm{O}$ & 12.96 & 2.3 & 0.81 & - & 1.76 \\
\hline 19 & $\begin{array}{c}\alpha- \\
\text { Bergamotene }\end{array}$ & $\mathrm{C}_{15} \mathrm{H}_{24}$ & 15.81 & - & - & 3.52 & - \\
\hline 20 & Caryophyllene & $\mathrm{C}_{15} \mathrm{H}_{24}$ & 15.91 & - & - & 3.82 & - \\
\hline
\end{tabular}

Major classes of primary chemicals

\begin{tabular}{|c|c|l|l|c|c|c|c|}
\hline (i) & Aldehydes & & & 34.76 & 16.66 & 66.71 & 41.80 \\
\hline (ii) & Alcohols & & & 46.53 & 59.08 & 17.04 & 46.72 \\
\hline (iii) & Esters & & & 16.41 & 15.21 & 6.62 & 9.69 \\
\hline (iv) & Ketones & & & 2.30 & 0.81 & - & 1.79 \\
\hline (v) & Ethers & & & - & 4.48 & - & - \\
\hline (vi) & Olefins & & & - & 3.76 & 9.63 & - \\
\hline (vii) & Total & & & 100 & 100 & 100 & 100 \\
\hline
\end{tabular}


The secondary metabolites that act as allelochemicals have small molecular weights and simple structures; these can include water-soluble organic acids, linear alcohols, fatty aldehydes and ketones, monounsaturated lactones, long-chain fatty acids, polyacetylenes, terpenes, amino acids, etc. (Rice 1984). The chemical compositions of the four rhododendron leaf samples were characterized by GC-MS (Table 1). There were 9, 11, 11, and 8 volatile compounds in the leaves of $R$. simsii, $R$. decorum, $R$. liliiflorum, and $R$. pulchrum, respectively. The main chemical substances in the acetone extract from the leaves of $R$. simsii, $R$. decorum, $R$. liliiflorum, and $R$. pulchrum are aldehydes and alcohols, of which aldehydes account for approximately $34.8 \%, 16.7 \%, 66.7 \%$, and $41.8 \%$, respectively, and alcohols account for approximately $46.5 \%, 59.1 \%, 17.0 \%$, and $46.7 \%$, respectively. (Table 1). These results indicated that the chemical compositions of the different rhododendron leaf samples were different, which may result in different allelopathic consequences. Among the identified compounds, alkane chemicals have been identified as having strong allelopathic effects (Rice 1984).

In this study, the analysis determined that the four kinds of rhododendron leaves are rich in chemical substances, but due to the use of acetone for soaking, the extract includes other acetone-soluble compounds, including non-volatile compounds. Among them, aldehydes and alcohols are the most famous seed germination inhibitors, which also include hydrocarbons, ketones, and esters (Bradow and Connick 1990). Macias (1995) used a unified standard biological test for various allelochemicals and found that esters and alcohols had strong allelopathic effects at low concentrations. Indeed, it has been shown that esters can have a significant inhibitory effect on seedling growth (Ma et al. 2014), and alcohols can inhibit seed germination (Gharachorloo et al. 2013; Pereira et al. 2014). Rhododendron leaves will all eventually become part of the litter layer in a rhododendron forest community, contributing nutrients to the forest soil and playing a vital role in the ecosystem (Zhou et al. 2014). However, the chemical substances contained in these leaves will also enter the soil as leaves decompose (Zhou et al. 2014; Dassot and Collet 2015). As these chemicals accumulate, they can have a toxic effect on the growth of understory plants, impeding forest regeneration (Li et al. 2019). Therefore, it is difficult for seedlings to take hold under the canopy of a rhododendron forest. The results provide a scientific basis for understanding the allelopathy of the forest and how it affects the natural regeneration of the rhododendron community.

Future research on the difficulty of the renewal of Baili Rhododendron forest should focus on the specific chemical substances produced in the Rhododendron forest and determine the effect of each chemical substance on the growth and development of Rhododendron.

\section{CONCLUSIONS}

This study identified 20 chemical substances in the leaves of $R$. simsii, $R$. decorum, $R$. liliiflorum, and $R$. pulchrum using GC-MS. They contained low molecular weight alcohols, aldehydes, and ester compounds. 


\section{ACKNOWLEDGMENTS}

The authors are grateful for the support of the National Natural Science Foundation of China, Grant No. 31460136/31960312; the National Key Research and Development Program of China, Grant No. 2016YFC0502602; the Provincial Natural Science Foundation of Guizhou, Grant No. QKHLH [2017]7354; QKZYD [2017] 4006; and the Forestry Science and Technology Project of Guizhou Province, Grant No. QLKH [2016] 09; QLKH [2018] 11.

\section{REFERENCES CITED}

Bradow, J. M., and Connick, W. J. (1990). "Volatile seed germination inhibitors from plant residues," Journal of Chemical Ecology 16(3), 645-666. DOI: 10.1007/BF01016477

Carillo, P., Cozzolino, C., D'Abrosca, B., Nacca, F., and Fuggi, A. (2010). "Effects of the allelochemicals dihydrodiconiferyl alcohol and lariciresinol on metabolism of Lactuca sativa," The Open Bioactive Compounds Journal 3, 18-24. DOI: $10.2174 / 1874847301003010018$

Chaintreau, A., Bicchi, C., and Rubiolo, P. (2018). "Quantifying the constituents of flavours, fragrances and essential oils," Flavour and Fragrance Journal 33(5), 337339. DOI: $10.1002 / f f j .3465$

Chen, X., Xie, B., Wu, H., and Huang, L. (2008). "Species and communities in Guizhou (China)," Acta Horticulture 769, 339-342. DOI: 10.17660/ActaHortic.2008.769.48

Chou, S. C., Huang, C. H., Hsu, T. W., Wu, C. C., and Chou, C. H. (2010). "Allelopathic potential of Rhododendron formosanum Hemsl in Taiwan," Allelopathy Journal 25, 73-91. DOI: 10.1021/ja308350f

Christina, M., Rouifed, S., Puijalon, S., Vallier, F., Meiffren, G., Bellvert, F. and Piola, F. (2015). "Allelopathic effect of a native species on a major plant invader in Europe," Science of Nature 102(3-4), 12. DOI:10.1007/s00114-015-1263-X

Dassot, M., and Collet, C. (2015). "Manipulating seed availability, plant competition and litter accumulation by soil preparation and canopy opening to ensure regeneration success in temperate low-mountain forest stands," European Journal of Forest Research 134(2), 1-13. DOI: 10.1007/s10342-014-0847-X

Fu, Y. H., Quan, W. X., Li, C. C., Qian, C. Y., Tang, F. H., and Chen, X. J. (2019). "Allelopathic effects of phenolic acids on seedling growth and photosynthesis in Rhododendron delavayi Franch," Photosynthetica 57(2), 377-387.

DOI: $10.32615 / p s .2019 .045$

Gharachorloo, M., Tarzi, B. G., and Baharinia, M. (2013). "The effect of germination on phenolic compounds and antioxidant activity of pulses," Journal of the American Oil Chemists' Society (3)90, 407-411. DOI: 10.1007/s11746-012-2170-3

Jensen, A. M., Löf, M., and Gardiner, E. S. (2011). "Effects of above- and below-ground competition from shrubs on photosynthesis, transpiration and growth in Quercus robur L. seedlings," Environmental and Experimental Botany 71(3), 367-375. DOI: 10.1016/j.envexpbot.2011.02.005

Li, C. C., Quan, W. X., Qian, C. Y., and Wu, Y. Y. (2019). "Distribution of chemical compounds in different soil layers of rhododendron forest," Allelopathy Journal 48 (2), 191-202. DOI: 10.26651/allelo. j/2019-48-2-1254 
Ma, T.-T., Christie, P., Luo, Y.-M., and Teng, Y. (2014). "Physiological and antioxidant responses of germinating mung bean seedlings to phthalate esters in soil," Pedosphere 24(1), 107-115. DOI: 10.1016/S1002-0160(13)60085-5

Macias, F. A. (1995). "Allelopathy in the search for natural herbicide models," Allelopathy Organisms Processes Appl. 582, 310-329. DOI: 10.1021/bk-1995-0582.ch023

Nilsen, E. T., Walker, J. F., Miller, O. K., Semones, S. W., and Clinton, L. B. D. (1999). "Inhibition of seedling survival under Rhododendron maximum (Ericaceae): Could allelopathy be a cause?" American Journal of Botany 86(11), 1597-1605.

DOI: $10.2307 / 2656796$

Pereira, E. P. L, Ribeiro, P. R., Loureiro, M. B., Castro, R. D., and Fernandez, L. G. (2014). "Effect of water restriction on total phenolics and antioxidant properties of Amburana cearensis (Fr. Allem) A.C. Smith cotyledons during seed imbibition," Acta Physiologiae Plantarum 36(5), 1293-1297. DOI: 10.1007/s11738-014-1503-2

Rice, E. L. (1984). "Chemical nature of allelopathic agents," Allelopathy (Second Edition) 266-291. DOI: 10.1016/b978-0-08-092539-4.50014-9

Shaoli, C., Baoli, Z., Shanshan, L., Xia, L., and Xueling, Y. (2011). “Accumulation of cinnamic acid and vanillin in eggplant root exudates and the relationship with continuous cropping obstacle," African Journal of Biotechnology 10(14). DOI: $10.5897 / A J B 10.1338$

Tomar, N. S., Sharma, M., and Agarwal, R. M. (2015). "Phytochemical analysis of Jatropha curcas L. during different seasons and developmental stages and seedling growth of wheat (Triticum aestivum L) as affected by extracts/leachates of Jatropha curcas L.," Physiology and Molecular Biology of Plants 21(1), 83.

DOI: $10.1007 / \mathrm{s} 12298-014-0272-0$

Touceda-González, Brader, M., Antonielli, G. L., Ravindran, V. B., Waldner, G., FrieslHanl, W., Corretto, E., Campisano, A., Pancher, M., and Sessitsch, A. (2015). "Combined amendment of immobilizers and the plant growth-promoting strain Burkholderia phytofirmans PsJN favours plant growth and reduces heavy metal uptake," Soil Biology and Biochemistry 91, 140-150.

DOI: 10.1016/j.soilbio.2015.08.038

Weir, T. L., Park, S. W., and Vivanco, J. M. (2004). "Biochemical and physiological mechanisms mediated by allelochemicals," Current Opinion in Plant Biology 7(4), 472-479. DOI: 10.1016/j.pbi.2004.05.007

Wu, Y. H, Liu, J. T., Yang, L. Z., Chen, H., Zhang, S. Q., Zhao, H. J., and Zhang, N. M. (2011). "Allelopathic control of cyanobacterial blooms by periphyton biofilms," Environmental Microbiology 13(3). DOI: 10.1111/j.1462-2920.2010. 02363.x

Zhou, Y., Su, J., Janssens, I. A., Zhou, G., and Xiao, C. (2014). "Fine root and litterfall dynamics of three Korean pine (Pinus koraiensis) forests along an altitudinal gradient," Plant and Soil 374(1-2), 19-32. DOI: 10.1007/s11104-013-1816-8

Article submitted: December 16, 2020; Peer review completed: January 16, 2021; Revised version received and accepted: February 27, 2021; Published: March 9, 2021. DOI: 10.15376/biores.16.2.3096-3102 